\title{
The Analysis of The Levels of Media and Television Literacy of High School Students in terms of Different Variables
}

\begin{tabular}{|c|c|}
\hline \multicolumn{2}{|c|}{$\begin{array}{l}{ }^{a} \text { Çukurova University, Faculty of Education, Adana/Turkey } \\
{ }^{\mathrm{b}} \text { Mersin ODTU Collage, Mersin/Turkey }\end{array}$} \\
\hline Article Info & Abstract \\
\hline DOI: 10.14812/cufej.2014.004 & $\begin{array}{l}\text { Knowledge mounts up, varies and is conveyed through different channels in each } \\
\text { passing day. Media includes all the circles that contain and convey the knowledge }\end{array}$ \\
\hline Article history: & itself. It is crucial for the young that are sensitive and affected easily to learn about the \\
\hline Received 07 June 2013 & structure and running of the mass media, to evaluate the fictionalized media content \\
\hline Revised $\quad 26$ January 2013 & consciously and watch critically, in other words, to be media literates. It has been seen \\
\hline Accepted 03 February 2014 & $\begin{array}{l}\text { that there is a lack of resources since the preparation of the project of applying the } \\
\text { Media and Television Literacy lessons in lesson programs by Radio and Television }\end{array}$ \\
\hline $\begin{array}{l}\text { Keywords: } \\
\text { Media, } \\
\text { Literacy, } \\
\text { Media and television literacy. }\end{array}$ & $\begin{array}{l}\text { Upper Board (2007) and it has been thought that media and TV literacy is studied } \\
\text { through various variables. Relational screening model is applied in this study and put } \\
\text { into practice with } 40212^{\text {th }} \text { grade high school students that are chosen according to the } \\
\text { intentional sampling method, among different school levels from state and private } \\
\text { schools. "Media and Television Literacy Level Scale", developed by Korkmaz and Yeşil } \\
\text { (2011), has been used in the research. Descriptive and Pearson's Product-Moment } \\
\text { Correlation Coefficient have been used in the data analysis. At the end of the study; } \\
\text { the findings have been as follows; media and TV literacy levels of the students are } \\
\text { high, and their addiction level is low, media and TV literacy points of the students do } \\
\text { not differ meaningfully according to their gender, school types, parent education } \\
\text { levels, general family structure and activities they like to take part in but media and TV } \\
\text { literacy level differs according to some individual characteristics, and that there is no } \\
\text { meaningful relationship between media and TV literacy points and academic success } \\
\text { points of the students. }\end{array}$ \\
\hline
\end{tabular}

\section{Introduction}

In addition that the media covers all the notions that include and distribute information, all kinds of printed, digital and electronic means of communication such as book, newspaper, journal, TV, radio can be a media (Andersen, 2002; cite in Karaman \& Karataş, 2009). Computer, internet, mobile phones, game consoles, handheld data banks (IPod), which are a part of daily life, or in other words all digital technologies are classified under the topic of new media. Addition to the opportunities that the media contributes, the growing diversity of the media and the power of it on the people of every age, the term media literacy has been arisen (Kurt \& Kürüm, 2010, pp. 20-34).

When the evolution of the media literacy in Turkey, it was first mentioned in the Communication Council in 2003; and, in the year of 2004, it was put on the ground by the offer of Radio Television Upper Commission (RTUC)to the Media and Violence Action Group working on the Action Plan. In the light of these studies, the Media Literacy course, which has been embodied in the education year of 2006-2007 with the cooperation of RTUC and the Ministry of National Education, has been put in the curriculum of the second part of the primary schools as an optional course.

*Corresponding author:baybek@cu.edu.tr 
The purpose of the course, put in action in the name of Media Literacy, was to help the children who are the most open and fragile to the media learn the structure and procedure of the mass communication; evaluate the media ingredients consciously; and watch them critically. These studies are important in terms of constitution of the conscious media culture. Nevertheless, it cannot be assumed enough to attain the results. When it is noticed that the children are exposed to media in very early ages, these skills should be acquired in early ages.

In the light of the explanations above, it can be said to be important that the young who constitutes the most open and fragile group to the media should learn the structure and procedure of the mass media, evaluate the media ingredients consciously; and watch them critically.

The main purpose of this study is to analyze the levels of media and television literacy of the high school students in terms of different variables.

In the direction of this purpose, answer s to those questions were sought:

1- What is the distribution of the students' media literacy course scores?

2- Are the student's course scores differentiate according to sex, type of school, graduate levels of parents, the dynamics of the family, leisure time activities and personal qualifications?

3- Is there a meaningful correlation between the students' literacy course scores and academic scores?

\section{Method}

In this research, relational scanning, which is among the scanning models, is used. Scanning model is a research model seeking to define a situation occurring now or in the past (Merter, 2009, p.84). The research was conducted in the districts of Toroslar, Yenişehir, Akdeniz, Erdemli and Tarsus, where the schooling is dense, during the 2011-2012 educational year. It was conducted with the 12th grade students in different public and private schools. 102 private, 98 public, 99 Anatolian and 103 vocational high school students has participated the research. The total was 200 girls and 202 boys, 402 totally.

Two data collection tools were used in the research. These were "personal Information tool" which was developed by the researchers and "the scale for Media and Television Literacy" developed by Korkmaz and Yeşil (2011). In the data analysis, in addition to descriptive statistics, Pearson product moment correlation was used. By taking the value of 0.05 level of significance, the results were analyzed in the direction of the purposes and then presented as tables and they were interpreted.

\section{Results}

At the end of the research, it was found that the level of media literacy of the students was high but the level of dependency of the students was low. It found that the scores of the students on the media and TV literacy has no meaningful difference in terms of gender, school type, the graduation level of their parents, the structure of their families and leisure time activities; but it was found that the scores of media and TV literacy differentiated. There was no meaningful difference between the students' scores of media and TV literacy and their academic success.

\section{Implementation}

Media Literacy Course was put in the curriculum -as an optional course- of second grade of the primary education during the educational year of 2007-2008 (RTÜK, 2008). However, most of the researchers have a consensus that that course should be implemented at earlier ages (Algan, 2006). Moreover, Desmond (1997) emphasizes that this education should begin at home. In the developed countries Media Literacy Course is either a compulsory course or embedded in different curriculums (RTÜK, 2008). By this terms, this Media Literacy Courses should be spread among the first phase of the primary education, be a multidisciplinary notion and be implemented at earlier ages. 
Birsel AYBEK \& Remzi DEMIR - Çukurova University Faculty of Education Journal, 43(1), 2014, 46-62

Media Literacy Courses should be taught by the qualified professional or the teachers who are going to teach that course should take in-service education.

Families should be educated on the subject of media Literacy in order to educate their children on the subject matter. So the families should have the Media Literacy Course via the life-long learning programs.

When the Media Literacy course is examined, it is seen that communication, media, society, culture, economics and mass media are included in the course (MEB and RTÜK, 2006). But there is no definite chapter on the power and the bad effects of media. There should be some chapters that students can encounter in their daily lives, easily understand and those chapters need to be detailed. 


\section{Lise Öğrencilerinin Medya ve Televizyon Okuryazarlık Düzeylerinin Çeşitli Değişkenler Açısından İncelenmesi}

\begin{tabular}{|c|c|}
\hline \multicolumn{2}{|c|}{ 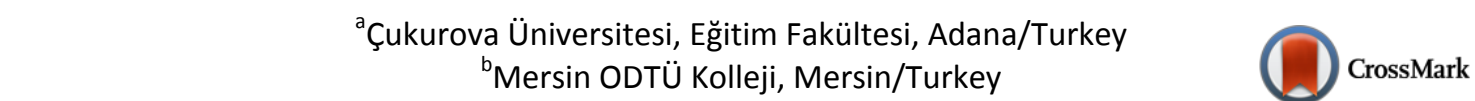 } \\
\hline Makele Bilgisi & Öz \\
\hline DOI: 10.14812/cufej.2014.004 & \multirow{6}{*}{ 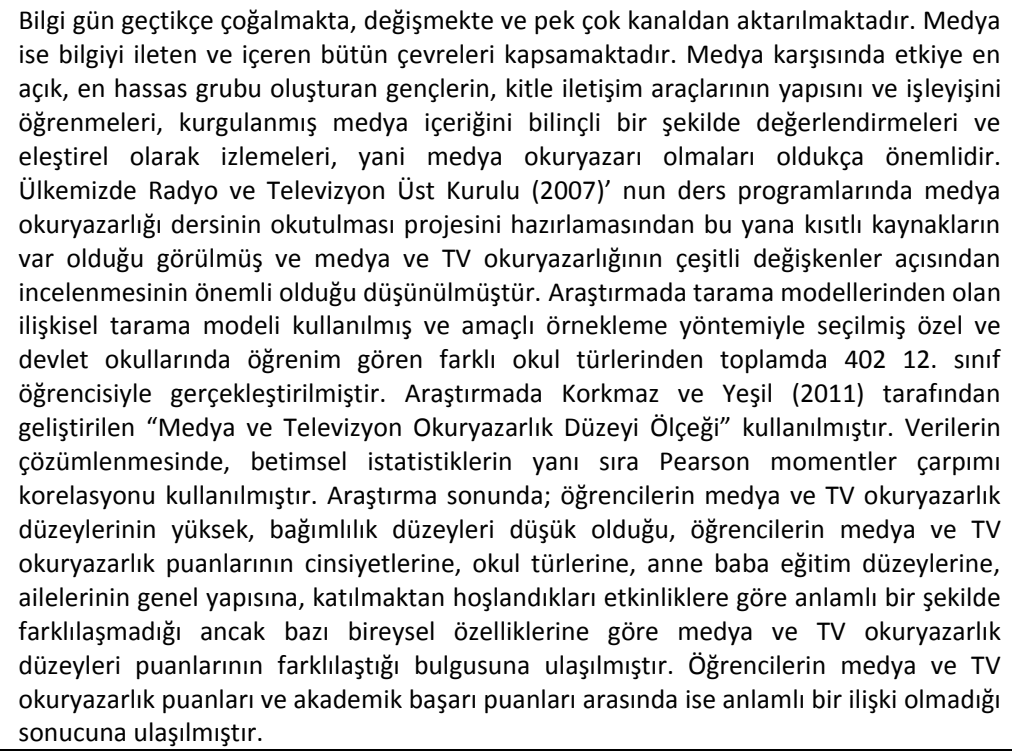 } \\
\hline Makale geçmişi: & \\
\hline Geliş $\quad 07$ Haziran 2013 & \\
\hline 26 Ocak 2014 & \\
\hline 03 Şubat 2014 & \\
\hline $\begin{array}{l}\text { Anahtar kelimeler: } \\
\text { Medya, } \\
\text { Okuryazarlık, } \\
\text { Medya ve televizyon okuryazarlığı. }\end{array}$ & \\
\hline
\end{tabular}

Giriş

Yazılı tarihin başlangıcından itibaren okuryazarlık kağıt üzerindeki çizgileri harf olarak görüp, bu harflerin yan yana getirilerek sözcük oluşturmak ve bu sözcüklerden anlam çıkarmak anlamına gelmektedir. Çocuklara, bu sözcüklerin birleştirilerek daha da karışık fikirlerin, yazıların anlam ve yorumlanmasını öğretmek yüzyıllar boyunca gelişen eğitimin amacı olmuştur. Bugünün öğrencilerinin bir şeyi bilmeye ihtiyaç duydukları zaman, neye ihtiyaçları olduğunu bulmayı öğrenmeye ihtiyaçları vardır. Eğer buldukları bilgi, bilmek istedikleri şey için gerekli ise "analiz ve değerlendirme" gibi üst düzey düşünme becerilerine sahip olmaları gerekmektedir (Thoman ve Jolls 2004; Akt. Kartal, 2007, s.1).

Medya bilgiyi ileten ve içeren bütün çevreleri kapsamakla birlikte, kitap, gazete, dergi, tv, radyo, internet gibi bilgiyi transfer eden her türlü basılı, dijital ve elektronik araç birer medya olabilir (Andersen, 2002; Akt. Karaman ve Karataş, 2009). Günlük yaşantının birer parçası haline gelen bilgisayar, internet, cep telefonları, oyun konsolları, avuç içi veri bankası kayıtlayıcıları (ıpod), bir başka deyişle tüm dijital teknolojiler yeni medya başlığı altında toplanmaktadır. Medyanın sağladığı olanakların yanı sıra

*Yazar: baybek@cu.edu.tr 
medyanın artan çeşitliliği ve bu çeşitliliğin her yaştaki bireyleri etkileme gücü, medya okuryazarlığı kavramını ortaya çıkarmıştır (Kurt ve Kürüm, 2010, s. 20-34).

Ülkemizde medya okuryazarlığııın öğrencilerin eğitimindeki önemini vurgulayan ve ilköğretim ders programında medya okuryazarlı̆̆ı dersinin okutulması projesini hazırlayan Radyo ve Televizyon Üst Kurulu (2007) ise, medya okuryazarlığını, "yazılı ve yazılı olmayan, büyük çeşitlilik gösteren formatlardaki (Televizyon, video, sinema, reklâmlar, internet vs.) mesajlara ulaşma, bunları çözümleme, değerlendirme ve iletme yeteneği kazanabilmek" olarak tanımlamıştır. Türkoğlu, medya okuryazarlığının yalnızca beceri kazanmaya değil, "eleştirel ve demokratik yurttaşlık" çerçevesinde günümüz toplumlarının yeni bir açığına vurgu yaptığını söyleyerek, kavramın, yalnızca pratik işlevsel ve araçsal bir gereksinimi değil, eleştirel aklın gerekliğini gündeme getirdiğini vurgulamaktadır (Akt. Çelik, 2008, s.224).

Medya okuryazarlığının Türkiye'deki gelişimi incelendiğinde, ilk olarak 2003 yılındaki iletişim Şurasında gündeme getirildiği, 2004 yılında ise Eylem Planı düzeyinde çalışan Medya ve Şiddet Çalışma Grubu'nun sonuç raporunda Radyo Televizyon Üst Kurulu (RTÜK) önerisiyle gündeme alındığı söylenebilir. Bu çalışmalar doğrultusunda RTÜK ve Milli Eğitim Bakanlığı' nın (MEB) işbirliği ile 2006-2007 öğretim yılında beş pilot ilde (Ankara, İstanbul, İzmir, Adana, Erzurum) okutulmaya başlanan medya okuryazarlığı dersi, 2007-2008 öğretim yılında ilköğretim II. kademede seçmeli ders olarak okutulmaya başlanmıştır.

Medya okuryazarlığı adı altında uygulamaya konan bu dersin amacı; medya karşısında etkiye en açık, en hassas grubu oluşturan çocukların, kitle iletişim araçlarının yapısını ve işleyişini öğrenmelerini, kurgulanmış medya içeriğini bilinçli bir şekilde değerlendirmelerini ve eleştirel olarak izlemelerini sağlamak olarak belirlenmiştir (Kurt ve Kürüm, 2010; MEB ve RTÜK, 2006). Medya okuryazarlığı dersi ile öğrencilere özel yaşamın gizliliğine saygı, estetik duyarııık, dürüstlük, sorumluluk, etik kurallara bağılık, farklııklara saygı duyma, kültürel mirası yaşatmaya duyarlıık, aile içi iletişime önem verme, bilinçli tüketim, toplumsal hayata aktif katılım, bilimsellik, eşitlik, yardımlaşma, dayanışma ve paylaşma gibi değerler kazandırılmak istenmektedir (MEB, 2009). Bu çalışmalar, bilinçli bir medya kültürünün oluşturulması açısından önemli bir girişimdir. Ancak amaca ulaşmada tek başına yeterli olması beklenemez. Medya okuryazarlığı ile ilgili olarak Hobbs (2004), medya metinleri hakkında soru sorma eylemi olan sorgulama pedagojisinin (izlediğiniz, gördüğünüz, okuduğunuz şeyler hakkında eleştirel sorular sorma), medya okuryazarlığı eğitiminin merkezinde yer alması gerektiğini ifade etmektedir. Jols ve Thoman (2008) medya mesajları hakkında beş temel soru sorulabileceğini ifade etmektedir. Bu sorular; "Bu mesaj kim tarafından yaratıldı?", "Bu mesajda ilgimi çekebilmek için ne tür teknikler kullanıldı?", "Bu mesajı diğer insanlar, benim anladığımdan farklı olarak nasıl anlamış olabilirler?", "Bu mesajda hangi yaşam biçimleri, değerler ve görüşlere yer verilirken, hangileri göz ardı edilmiştir?" ve "Bu mesaj niçin gönderilmiştir?" şeklindedir. Özellikle çok erken yaşlarda çocukların medyayla tanıştıkları dikkate alındığında bu becerilerin daha erken yaşlarda kazandırılması gerekmektedir.

\section{Problem}

Yukarıdaki açıklamalar doğrultusunda medya karşııında etkiye en açık, en hassas grubu oluşturan gençlerin, kitle iletişim araçlarının yapısını ve işleyişini öğrenmeleri, kurgulanmış medya içeriğini bilinçli bir şekilde değerlendirmeleri ve eleştirel olarak izlemelerinin önemli olduğu söylenilebilir. Radyo ve Televizyon Üst Kurulu (2007)'nun ders programlarında medya okuryazarlığı dersinin okutulması projesini hazırlamasından bu yana kısıtı kaynakların var olduğu görülmüş ve medya ve TV okuryazarlığııın çeşitli değişkenler açısından incelenmesinin eğitim ve öğretim sürecine önemli katkılar sunacağı düşünülmüştür.

$\mathrm{Bu}$ amaçla bu çalışmanın temel amacı, lise öğrencilerinin medya ve televizyon okuryazarlık düzeylerinin çeşitli değişkenler açısından incelenmesidir. Bu temel amaç doğrultusunda şu sorulara cevap aranmıştır: 
1-Öğrencilerin medya ve TV okuryazarlık düzeyi puanlarının dağııımı nasıldır?

2-Öğrencilerin medya ve TV okuryazarlık puanları cinsiyet, okul türü, anne-baba eğitim düzeyi, ailenin genel yapısı, katılmaktan hoşlanılan etkinlikler, bireysel özellikler değişkenlerine göre farklılaşmakta midır?

3- Öğrencilerin medya ve TV okuryazarlık puanları ve akademik başarı puanları arasında anlamlı bir ilişki var mıdır?

\section{Yöntem}

\section{Araştırmanın Modeli}

Bu araştırmada tarama modellerinden olan ilişkisel tarama modeli kullanılmıştır. Tarama modeli, geçmişte veya şu anda var olan bir durumu var olduğu şekliyle betimlemeyi amaçlayan araştırma modelleridir (Merter, 2009, s.84). iliş̧isel tarama modelleri, araştırma iki ve daha çok sayıdaki değişken arasında birlikte değişimin varlığı ve/veya derecesini araştıran genel tarama modellerinden ilişkisel tarama modelidir. Bunlar, korelasyon ve karşılaştırmadır (Karasar, 1998, s. 81).

\section{Evren ve Örneklem}

Araştırma, Mersin ilinde okulların yoğun olarak bulunduğu Toroslar, Yenişehir, Akdeniz merkez ilçelerinde ve Erdemli, Tarsus ilçelerinde 2011-2012 eğitim-öğretim yııında amaçlı örnekleme yöntemiyle seçilmiş özel ve devlet okullarında öğrenim gören farklı okul türlerinde 12. sınıf öğrencileriyle gerçekleştirilmiştir. Araştırmaya, 102 Özel, 98 Genel, 99 Anadolu ve 103 meslek lisesi öğrencisi katılmışır. Bu öğrenciler, 200 Kız ve 202 Erkek olmak üzere toplam 402 kişidir.

\section{Veri Toplama Araçları}

Araştırmada iki veri toplama aracı kullanılmışır. Bunlar; araştırmacılar tarafından geliştirilen "Kişisel Bilgi Formu" ve Korkmaz ve Yeşil (2011) tarafından geliştirilen “Medya ve Televizyon Okuryazarlık Düzeyi Ölçeği"dir.

Öğrencilerin Medya ve televizyon okuryazarlık düzeylerini belirlemek için Korkmaz ve Yeşil (2011) tarafından geliştirilen Medya ve Televizyon Okuryazarlık Düzeyleri Ölçeği kullanılmıştır. Ölçek beş basamaklı likert tipi bir ölçektir ve "Okuryazarlık ve bağımlılık" olmak üzere iki faktörden oluşmaktadır. Faktörlerde yer alan maddelerin her biri; hiçbir zaman (1) Asla, (2) Nadiren, (3) Bazen, (4) Genellikle, (5) her zaman şeklinde derecelendirilmiştir. Ölçekte, "Okuryazarlık" faktörü 13 maddeyi içermektedir ve maddelerin faktör yükleri 0.484 ile 0.774 arasında değişmektedir. Bu faktörün genel ölçek içerisindeki öz değeri 7.692; genel varyansa sağladığı katkı miktarı ise \% 32.768'dir. "Bağımlııı" faktörü ise 5 maddeyi içermektedir ve maddelerin faktör yükleri 0.662 ile 0.826 arasındadır. Faktörün genel ölçek içerisindeki öz değeri 2.242; genel varyansa sağladığı katkı miktarı ise \% 22.420'dir (Korkmaz ve Yeşil, 2011).

Toplam 18 maddeden ve 2 faktörden oluşan ölçeğin faktörlere göre ve bütün olarak güvenirlik analizi; Cronbach alpha güvenirlik katsayısı, iki eş yarı arasındaki korelasyon değeri, Sperman-Brown formülü ve Guttmann split-half güvenirlik formülü kullanılarak hesaplanmıştır. Ölçeğin sırasıyla okuryazarlık (13 madde) ve bağımlılık ( 5 madde) faktörlerine göre Cronbach alpha güvenirlik katsayıları okuryazarlık için 0.914 , bağımlılık için 0.851; eş yarı korelasyonları okuryazarlık için 0.750 , bağımlılık için 0.718; Sperman Brown değerleri okuryazarlık için 0.857, bağımlılık için 0.836; son olarak Guttmann SplitHalf değerleri ise okuryazarlık için 0.857 , bağımlıık için ise 0.799 olarak bulunmuştur (Korkmaz ve Yeşil, 2011).

Okuryazarlık faktöründen elde edilen puanlara karşılık gelen düzeyler şu şekilde özetlenebilir:

20-35: Çok Düşük Okuryazarlık Düzeyi

36-51: Düşük Okuryazarlık Düzeyi 
52-67: Orta Düzey Okuryazarlık

68-83: Yüksek Okuryazarlık Düzeyi

84-100: Çok Yüksek Okuryazarlık Düzeyi

Bağımlılık faktöründen elde edilen puanlar da benzer aralıklarla dağılmaktadır. Ancak okuryazarlık ile bağımlılık ters orantılıdır. Okuryazarlık düzeyi yüksek olan bir bireyin bağımlılık düzeyinin düşük olması beklenir. Bağımlılık puanlarının yüksek olması bireyin bağımlılığının yüksek, dolayısıyla okuryazarlık düzeyinin düşük olduğunu gösterir (Yeşil ve Korkmaz, 2011). Bu araştırma için ölçeğin Cronbach alpha güvenirlik katsayıları yeniden hesaplanmış ve okuryazarlık için bu katsayı 0.76, bağımlılık için ise 0.68 olarak bulunmuştur.

\section{Verilerin Analizi}

Verilerin çözümlenmesinde, betimsel istatistiklerin yanı sıra, Pearson momentler çarpımı korelasyonu kullanılmıştır. Tüm istatistiksel analizlerde 0.05 anlamlılık düzeyi ölçüt alınarak araştırma bulguları, amaçlar doğrultusunda analiz edildikten sonra, tablolar halinde sunulmuş ve yorumlanmıştır.

\section{Bulgular}

Bu bölümde öğrencilerin medya ve TV okuryazarlık düzeyi puanlarının dağılımı, medya ve TV okuryazarlık düzeyi; cinsiyet, okul türü, anne-baba eğitim düzeyi, ailenin genel yapısı, katılmaktan hoşlanılan etkinlikler, bireysel özellikler değişkenlerine göre farklılaşıp farklılaşmadıkları hakkında ve öğrencilerin medya ve TV okuryazarlık düzeyi puanları ile akademik başarı puanları arasında anlamlı bir ilişki olup olmadığı hakkında elde edilen bulgulara yer verilmiştir.

\section{Öğrencilerin Medya ve Televizyon Okuryazarlık Düzeyleri Puanlarının Dağılımına ilişkin Bulgular}

Öğrencilerin Medya ve Televizyon Okuryazarlık düzeyleri puanları iki bölümde incelenmiştir. Aşağıda Tablo 1 incelendiğinde, öğrencilerin medya ve televizyon okuryazarlık düzeyi ortalamasının yüksek düzeyde ( $\bar{X}=79.83)$, bağımlılık düzeylerinin ise düşük düzeyde $(\bar{X}=43.72)$ olduğu görülmüştür.

Tablo 1.

Öğrencilerin Medya ve Televizyon Okuryazarlık Puanları Ortalama, En Düşük, En Yüksek ve Standart Sapma Değerleri.

\begin{tabular}{lccccc}
\hline Medya ve Televizyon Okuryazarlık & $\mathrm{N}$ & $\overline{\mathrm{X}}$ & En düşük & En yüksek & Ss \\
\hline Okuryazarlık & 402 & 79.83 & 20 & 100 & 10.81 \\
Bağımlılık & 402 & 43.72 & 20 & 100 & 19.57 \\
\hline
\end{tabular}

\section{Öğrencilerin Medya ve Televizyon Okuryazarlık Düzeyleri Puanlarının Bazı Değişkenlere Göre Farklılaşıp Farklılaşmamasına ilişskin Bulgular}

Bu bölümde öğrencilerin medya ve televizyon okuryazarlık düzeyleri puanlarının, cinsiyetlerine, okul türlerine, anne-baba eğitim düzeylerine, ailelerinin genel yapısına, katılmaktan hoşlandıkları etkinliklere ve bireysel özelliklerine göre anlamlı bir şekilde farklılaşıp farklılaşmamasına ilişkin bulgulara yer verilmiştir.

\section{Öğrencilerin medya ve televizyon okuryazarlık düzeyleri puanlarının cinsiyetlerine göre farkıılaşıp} farklılaşmamasına ilişkin bulgular

Öğrencilerin medya ve televizyon okuryazarlık düzeyleri puanları ile cinsiyetleri arasında anlamlı bir farklılaşma var mıdır? sorusuna yanıt bulabilmek için $t$ testi analizi yapılmıştır. Analiz sonuçları aşağıda Tablo 2' de yer almaktadır. Tabloda da görüldüğü gibi anlamlı bir farklılaşma olmadığı sonucuna ulaşılmıştır. 
Tablo 2.

Öğrencilerin Medya ve Televizyon Okuryazarlık Düzeyleri Puanlarının Cinsiyetlerine Göre Farklılaşıp Farklılaşmamasına iliş̧kin Değerler.

\begin{tabular}{lllcccc}
\hline Medya ve TV Okuryazarlık & Cinsiyet & $\mathrm{N}$ & $\overline{\mathrm{X}}$ & $\mathrm{Ss}$ & $\mathrm{T}$ & $\mathrm{p}$ \\
\hline Okuryazarlık & Kız & 200 & 79.63 & 10.30 & -.365 & .715 \\
& Erkek & 202 & 80.02 & 11.32 & & \\
\hline Bağımlılık & Kız & 200 & 43.16 & 18.10 & -.572 & .568 \\
& Erkek & 202 & 44.27 & 20.97 & & \\
\hline$p>0.05$ & & & & & &
\end{tabular}

Öğrencilerin medya ve televizyon okuryazarlık düzeyleri puanlarının okul türlerine göre farklılaşıp farklılaşmamasına ilişkin bulgular

Öğrencilerin medya ve televizyon okuryazarlık düzeyleri puanlarının okul türlerine göre farklılaşıp farkılıaşmadığını belirlemek için tek yönlü varyans analizi yapılmış ve Tablo $3^{\prime}$ de görüldüğü gibi herhangi anlamlı bir farklılaşmanın olmadığı bulgusuna ulaşılmıştır.

Tablo 3.

Öğrencilerin Medya ve Televizyon Okuryazarlık Düzeyleri Puanlarının Okul Türlerine Göre Farklılaşıp Farklılaşmamasına ilişkin Değerler.

\begin{tabular}{lllcccc}
\hline Medya ve TV Okuryazarlık & Okul Türü & $\mathrm{N}$ & $\overline{\mathrm{X}}$ & $\mathrm{Ss}$ & $\mathrm{F}$ & $\mathrm{p}$ \\
\hline Okuryazarlık & Özel & 102 & 78.83 & 11.49 & .487 & .691 \\
& Genel & 98 & 80.04 & 12.00 & & \\
& Anadolu & 99 & 80.64 & 10.02 & & \\
& Meslek & 103 & 79.84 & 9.68 & & \\
& Toplam & 402 & 79.83 & 10.81 & & \\
\hline Bağımlılık & Özel & 102 & 44.86 & 20.25 & .448 & .719 \\
& Genel & 98 & 44.04 & 20.68 & & \\
& Anadolu & 99 & 44.16 & 18.54 & & \\
& Meslek & 103 & 41.86 & 18.93 & & \\
& Toplam & 402 & 43.72 & 19.57 & & \\
& & & & & &
\end{tabular}

$p>0.05$

Öğrencilerin medya ve televizyon okuryazarlık düzeyleri puanlarının anne- baba eğitim düzeylerine göre farkılıaşıp farklılaşmamasına ilişkin bulgular

Bu alt amaca yönelik tek yönlü varyans analizi yapılarak ulaşılan değerler, aşağıda Tablo 4 ve 5'te verilmiştir.

Bu değerlere göre öğrencilerin medya ve TV okuryazarlık düzeyi puanlarının anne- baba eğitim düzeyine göre anlamlı bir farklılaşma göstermediği, öğrencilerin puanlarının aritmetik ortalamalarındaki farkııı̆ın rastlantısal olduğu bulgusuna ulaşılmıştır.

Öğrencilerin medya ve televizyon okuryazarlık düzeyleri puanlarının, ailelerinin genel yapısına göre anlamlı bir şekilde farklılaşıp farklılaşmamasına ilişkin bulgular

Öğrencilerin medya ve TV okuryazarlık düzeyi puanlarının aile yapılarına göre anlamlı bir şekilde farklılaşıp farklılaşmadığıı belirleyebilmek için tek yönlü varyans analizi yapılmıştır. Analiz sonucunda anlamlı bir farkıılaşma olmadığı görülmüştür. Değerler aşağıda Tablo 6’ da verilmiştir. 
Tablo 4.

Öğrencilerin Medya ve Televizyon Okuryazarlık Düzeyleri Puanlarının Anne Eğitim Düzeylerine Göre Farklılaşıp Farklılaşmamasına iliş̧kin Değerler.

\begin{tabular}{|c|c|c|c|c|c|c|c|}
\hline $\begin{array}{l}\text { Medya ve } \\
\text { Okuryazarlık }\end{array}$ & TV & Anne Eğitim Düzeyi & $N$ & $\overline{\mathrm{X}}$ & Ss & $F$ & $p$ \\
\hline \multirow{8}{*}{\multicolumn{2}{|c|}{ Okuryazarlık }} & Okuryazar Değil & 33 & 82 & 8.74 & .433 & .857 \\
\hline & & Okuryazar & 20 & 81.15 & 7.90 & & \\
\hline & & İlkokul & 104 & 80.07 & 10.74 & & \\
\hline & & Ortaokul & 61 & 79.83 & 11.81 & & \\
\hline & & Lise & 112 & 79.14 & 10.17 & & \\
\hline & & Yüksek Öğrenim & 54 & 78.83 & 13.30 & & \\
\hline & & Lisans Üstü & 18 & 80.27 & 10.35 & & \\
\hline & & Toplam & 402 & 79.83 & 10.81 & & \\
\hline \multirow{8}{*}{\multicolumn{2}{|c|}{ Bağımlılık }} & Okuryazar Değil & 33 & 44.96 & 20.05 & 1.231 & .289 \\
\hline & & Okuryazar & 20 & 48.40 & 18.84 & & \\
\hline & & İlkokul & 104 & 40.26 & 18.47 & & \\
\hline & & Ortaokul & 61 & 46.95 & 20.06 & & \\
\hline & & Lise & 112 & 42.67 & 19.12 & & \\
\hline & & Yüksek Öğrenim & 54 & 45.25 & 20.81 & & \\
\hline & & Lisans Üstü & 18 & 47.11 & 22.27 & & \\
\hline & & Toplam & 402 & 43.72 & 19.57 & & \\
\hline
\end{tabular}

$p>0.05$

Tablo 5.

Öğrencilerin Medya ve Televizyon Okuryazarlık Düzeyleri Puanlarının Baba Eğitim Düzeylerine Göre Farklılaşıp Farklılaşmamasına ilişkin Değerler.

\begin{tabular}{|c|c|c|c|c|c|c|c|}
\hline $\begin{array}{l}\text { Medya ve } \\
\text { Okuryazarlık }\end{array}$ & TV & Baba Eğitim Düzeyi & $\mathrm{N}$ & $\overline{\mathrm{X}}$ & Ss & $F$ & $\mathrm{p}$ \\
\hline \multirow{8}{*}{\multicolumn{2}{|c|}{ Okuryazarlık }} & Okuryazar Değil & 33 & 72.66 & 12.83 & 1.220 & .295 \\
\hline & & Okuryazar & 20 & 84.29 & 4.93 & & \\
\hline & & ilkokul & 104 & 80.00 & 8.88 & & \\
\hline & & Ortaokul & 61 & 80.43 & 9.04 & & \\
\hline & & Lise & 112 & 78.73 & 10.45 & & \\
\hline & & Yüksek Öğrenim & 54 & 80.22 & 12.84 & & \\
\hline & & Lisans Üstü & 18 & 80.66 & 14.99 & & \\
\hline & & Toplam & 402 & 79.83 & 10.81 & & \\
\hline \multirow{8}{*}{\multicolumn{2}{|c|}{ Bağımlılık }} & Okuryazar Değil & 33 & 53.33 & 25.25 & .789 & .579 \\
\hline & & Okuryazar & 20 & 46.11 & 17.09 & & \\
\hline & & İlkokul & 104 & 43.04 & 19.05 & & \\
\hline & & Ortaokul & 61 & 45.74 & 20.75 & & \\
\hline & & Lise & 112 & 44.22 & 19.19 & & \\
\hline & & Yüksek Öğrenim & 54 & 40.61 & 19.64 & & \\
\hline & & Lisans Üstü & 18 & 45.20 & 20.80 & & \\
\hline & & Toplam & 402 & 43.72 & 19.57 & & \\
\hline
\end{tabular}

$p>0.05$ 
Tablo 6.

Öğrencilerin Medya Ve TV Okuryazarlık Düzeyi Puanlarının Aile Yapılarına Göre Anlamlı Bir Şekilde Farklılaşıp Farklılaşmamasına iliş̧kin Değerler.

\begin{tabular}{|c|c|c|c|c|c|c|c|}
\hline \multicolumn{8}{|l|}{ Okuryazarlık } \\
\hline \multirow{6}{*}{\multicolumn{2}{|c|}{ Okuryazarlık }} & Otoriter & 44 & 79.56 & 10.35 & .966 & .426 \\
\hline & & Demokratik & 166 & 80.27 & 11.26 & & \\
\hline & & İlgisiz & 10 & 85.60 & 9.93 & & \\
\hline & & Aşırı İlgili & 57 & 78.87 & 9.34 & & \\
\hline & & Koruyucu & 125 & 79.32 & 11.04 & & \\
\hline & & Toplam & 402 & 79.83 & 10.81 & & \\
\hline \multirow[t]{6}{*}{ Bağımlılık } & & Otoriter & 44 & 44.00 & 18.46 & 1.362 & .246 \\
\hline & & Demokratik & 166 & 43.66 & 19.93 & & \\
\hline & & İlgisiz & 10 & 30.80 & 18.38 & & \\
\hline & & Aşırı İlgili & 57 & 42.45 & 18.77 & & \\
\hline & & Koruyucu & 125 & 45.31 & 19.81 & & \\
\hline & & Toplam & 402 & 43.72 & 19.57 & & \\
\hline
\end{tabular}

$P>0.05$

Öğrencilerin medya ve televizyon okuryazarlık düzeyleri puanlarının, katılmaktan hoşlandıkları etkinliklere göre anlamlı bir şekilde farklılaşıp farklılaşmamasına ilişkin bulgular

Yapılan tek yönlü varyans analizi sonuçları aşağıda Tablo 7'de verilmiştir. Analiz sonucunda öğrencilerin medya ve TV okuryazarlık düzeyi puanlarının katılmaktan hoşlandıkları etkinliklere göre farklılaşmadığı bulgusuna ulaşılmıştır.

Tablo 7.

Öğrencilerin Medya ve Televizyon Okuryazarlık Düzeyleri Puanlarının, Katılmaktan Hoşlandıkları Etkinliklere Göre Anlamlı Bir Şekilde Farklılaşıp Farklılaşmamasına ilişkin Değerler.

\begin{tabular}{|c|c|c|c|c|c|c|c|}
\hline \multicolumn{8}{|l|}{ Okuryazarlık } \\
\hline \multirow{5}{*}{\multicolumn{2}{|c|}{ Okuryazarlık }} & Bilimsel & 56 & 80.85 & 11.22 & 1.622 & .184 \\
\hline & & Kültürel & 167 & 80.91 & 9.30 & & \\
\hline & & Sportif & 163 & 78.49 & 10.53 & & \\
\hline & & Diğer & 16 & 78.62 & 21.72 & & \\
\hline & & Toplam & 402 & 79.83 & 10.81 & & \\
\hline \multirow{5}{*}{\multicolumn{2}{|c|}{ Bağımlılık }} & Bilimsel & 56 & 45.85 & 17.17 & 1.107 & .346 \\
\hline & & Kültürel & 167 & 42.97 & 19.89 & & \\
\hline & & Sportif & 163 & 43.04 & 19.33 & & \\
\hline & & Diğer & 16 & 51.00 & 25.81 & & \\
\hline & & Toplam & 402 & 43.72 & 19.57 & & \\
\hline
\end{tabular}

$p>0.05$

Öğrencilerin medya ve televizyon okuryazarlık düzeyleri puanlarının, bireysel özelliklerine göre anlamlı bir şekilde farklılaşıp farklılaşmamasına ilişkin bulgular

Yapılan tek yönlü varyans analizi sonucunda öğrencilerin medya ve TV okuryazarlık düzeyleri puanlarının medya okuryazarlığı açısından 0.05 anlamlılık düzeyinde farklılaştığı bulgusuna ulaşıımıştır. Bu farklılaşmanın kaynağını belirlemek üzere LSD testi uygulanmıştır. Elde edilen değerler aşağıda Tablo 8' de verilmiştir. 
Aşağıdaki değerler incelendiğinde 0.05 anlamlılık düzeyinde öğrencilerin bağımlılık puanlarının anlamlı bir farklılaşma göstermediği bulgusuna ulaşılmıştır. Ancak medya okuryazarlığı açısından oluşan anlamlı farklılaşmanın kaynağı LSD testi ile incelendiğinde; kendine güvenen öğrencilerin $(\overline{\mathrm{X}}=80.18)$ risk alabilen öğrencilerden $(\bar{X}=75.97)$, düşünmeye önem veren öğrencilerin $(\bar{X}=81.13)$ risk alabilen öğrencilerden $(\overline{\mathrm{X}}=75.97)$ ve kendine güvenen öğrencilerden $(\overline{\mathrm{X}}=80.18)$, yaratıc öğrencilerin $(\overline{\mathrm{X}}=82.95)$ girişken $(\bar{X}=76.70)$, risk alabilen $(\bar{X}=75.97)$ ve kendine güvenen öğrencilerden $(\bar{X}=80.18)$, sorgulayıc öğrencilerin $(\bar{X}=85.92)$, girişken $(\bar{X}=76.70)$, risk alabilen $(\bar{X}=75.97)$, sorumluluk üstlenebilen $(\bar{X}=79.44)$, kendine güvenen $(\bar{X}=80.18)$, yeni fikirlere açık $(\bar{X}=79.19)$ ve insancıl $(\bar{X}=78.65)$ öğrencilerden farklılaştıkları ve medya ve TV okuryazarlık düzeylerinin daha gelişmiş olduğu bulgularına ulaşılmıştır. Özellikle sorgulayıc öğrencilerin diğer 6 özelliğe sahip olan öğrencilerden (Girişken, risk alabilen, sorumluluk üstlenebilen, kendine güvenen, yeni fikirlere açık ve insancıl) anlamlı olarak farklılaştığı ve medya ve TV okuryazarlık düzeylerinin daha gelişmiş olduğu tespit edilmiştir.

Tablo 8.

Öğrencilerin Medya ve Televizyon Okuryazarlık Düzeyleri Puanlarının, Bireysel Özelliklerine Göre Anlamlı Bir Şekilde Farklılaşıp Farklılaşmamasına ilişskin Değerler.

\begin{tabular}{|c|c|c|c|c|c|c|c|c|}
\hline $\begin{array}{l}\text { Medya ve } \\
\text { Okuryazarlık }\end{array}$ & \multicolumn{7}{|c|}{ Okuryazarlık } & $\mathrm{p}$ \\
\hline \multirow[t]{11}{*}{ Okuryazarlık } & & (1)Araştırıcı & 29 & 80.62 & 12.79 & $2.160 *$ & $5>3$ & .024 \\
\hline & & (2)Girişken & 27 & 76.70 & 9.44 & & $8>3,5$ & \\
\hline & & (3)Risk Alan & 39 & 75.97 & 17.47 & & $9>2,3,5$ & \\
\hline & & (4)Sorumlu & 59 & 79.44 & 9.30 & & $10>2,3,4,5$, & \\
\hline & & (5)Kendine Güvenen & 88 & 80.18 & 8.97 & & 6,7 & \\
\hline & & (6)Açık Fikirli & 31 & 79.19 & 8.12 & & & \\
\hline & & (7)İnsancıl & 44 & 78.65 & 9.20 & & & \\
\hline & & (8)Düşünceli & 38 & 81.13 & 9.04 & & & \\
\hline & & (9)Yaratıcı & 20 & 82.95 & 14.42 & & & \\
\hline & & (10)Sorgulayıcı & 27 & 85.92 & 7.75 & & & \\
\hline & & Toplam & 402 & 79.83 & 10.81 & & & \\
\hline \multirow[t]{11}{*}{ Bağımlılık } & & Araştırıcı & 29 & 48.27 & 19.00 & 1.661 & & .096 \\
\hline & & Girişken & 27 & 45.33 & 20.06 & & & \\
\hline & & Risk Alan & 39 & 43.28 & 23.01 & & & \\
\hline & & Sorumlu & 59 & 41.15 & 17.40 & & & \\
\hline & & Kendine Güvenen & 88 & 40.81 & 18.21 & & & \\
\hline & & Açık Fikirli & 31 & 47.87 & 21.42 & & & \\
\hline & & İnsancıl & 44 & 51.45 & 21.67 & & & \\
\hline & & Düşünceli & 38 & 42.31 & 19.23 & & & \\
\hline & & Yaratıcı & 20 & 39.80 & 16.69 & & & \\
\hline & & Sorgulayıcı & 27 & 40.44 & 17.51 & & & \\
\hline & & Toplam & 402 & 43.72 & 19.57 & & & \\
\hline
\end{tabular}

${ }^{*} \mathrm{p}<0.05$

Öğrencilerin Medya ve Televizyon Okuryazarlık Düzeyleri Puanları ve Akademik Başarı Puanları Arasındaki iliş̧kiye Yönelik Bulgular

Öğrencilerin medya ve TV okuryazarlık düzeyleri puanları ile akademik başarı puanları arasında anlamlı bir ilişki olup olmadığını tespit etmek üzere Person Korelasyon analizi yapılmıştır. Aşağıda Tablo 9'da yer alan korelasyon değerleri incelendiğinde $p>0.05$ olduğu yani öğrencilerin medya ve TV okuryazarlık düzeyi puanları ve akademik başarı puanları arasında anlamlı bir ilişki olmadığı sonucuna ulaşılmıştır. 
Tablo 9.

Öğrencilerin Medya ve Televizyon Okuryazarlık Düzeyleri Puanları ve Akademik Başarı Puanları Arasındaki Korelasyon Değerleri.

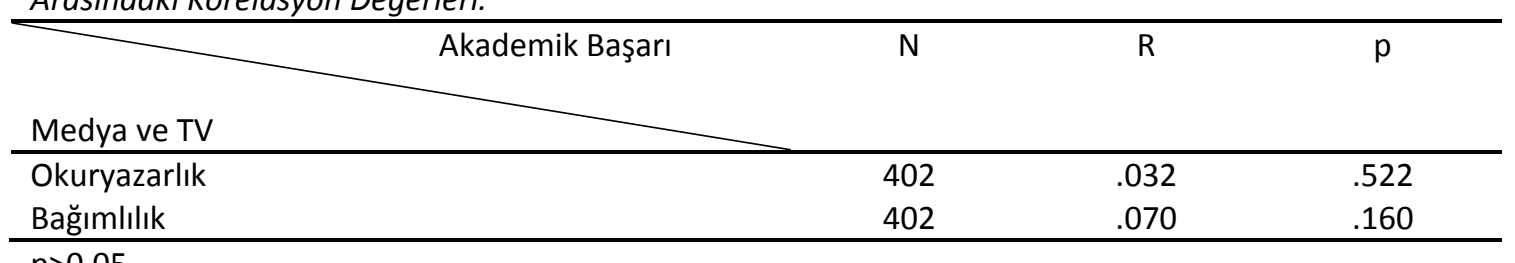

$p>0.05$

\section{TARTIŞMA ve YORUM}

Aşağıda öncelikle, araştırmada elde edilen bulgular, özetlenerek Tablo 10'da verilmiştir. Daha sonra ise çıkan bulgular araştırmanın amaçları doğrultusunda sırayla tartışılmış ve yorumlanmıştır

Tablo 10.

Araştırmadan Elde Edilen Bulguların Özeti.

\begin{tabular}{ll}
\hline MEDYA VE TV OKURYAZARLIK DÜZEYLERi & $\begin{array}{l}\text { Okuryazarlık Yüksek } \\
\text { Bağımlılık Düşük }\end{array}$ \\
\hline Cinsiyete Göre Farklılaşma & Yok \\
Okul Türlerine Göre Farklılaşma & Yok \\
Anne, Baba Eğt. Düzeyine Göre Farklılaşma & Yok \\
Ailelerin Yapısına Göre Farklılaşma & Yok \\
Katılmaktan Hoşlandıkları Etkinliklere Göre & Yok \\
Bireysel Özelliklerine Göre & Bağımlılık yok. \\
& $\begin{array}{l}\text { Okuryazarlık } \\
\text { Sorgulayıcı > Girişken, Risk alabilen, } \\
\text { Sorumluluk üstlenebilen, Kendine güvenen, } \\
\text { Yeni fikirlere açık, Insancıl. }\end{array}$ \\
\hline
\end{tabular}

\section{Öğrencilerin Medya ve Televizyon Okuryazarlık Düzeyleri Puanlarının Dağılımına iliş̧kin Tartışma ve} Yorumlar

Öğrencilerin iki bölümde incelenen Medya ve Televizyon Okuryazarlık düzeyleri puanları, okuryazarlık ve bağımlılık olmak üzere ters orantılıdır. Öğrencilerin Medya ve TV okuryazarlık düzeyi ortalamasının yüksek düzeyde ( $\bar{X}=79.83)$, bağımlılık düzeylerinin ise düşük düzeyde $(\bar{X}=43.72)$ olduğu görülmüştür. Bulgulara yönelik alan yazın incelendiğinde Korkmaz ve Yeşil (2011)' in de vurguladığı üzere medya ve okuryazarlık ile ilgili yapılan çalışmaların ağırlıklı olarak kuramsal nitelik gösterdiği, anket ve ölçek kullanımına dayalı çalışmaların daha az olduğu diğer taraftan anket ve ölçek kullanımına dayanarak yürütülen çalışmalarda ise daha çok tutum belirleme üzerine odaklanıldığı; öğrencilerin ya da öğretmenlerin okuryazarlık düzeylerini belirlemeye dönük çalışmaların ise genel olarak yapılmadığı söylenebilir. Kartal (2007), “Orta öğretim 10. sınıf öğrencilerinin televizyon dizilerindeki mesajları algılamalarında medya okuryazarlığının etkisi" isimli yüksek lisans araştırmasında öğrencilerin medya okuryazarlık düzeyleri konusunda, medyaya eleştirel yaklaşım davranışının belli bir seviyede olduğu sonucuna ulaşmıştır. Ancak öğrencilerin sahip oldukları bilgi ve becerilerini davranışlarına yansıtabilmeleri konusunda bazı önerilerde de bulunmuştur. Yine Algan (2006, s.39) birçok orta, lise ve üniversite öğretmeninin öğrencilerinin medyanın bir kurbanı oldukları ve popüler kültürün aşırılık ve kötülüklerinden korunmaya ihtiyaçları olduğu fikrinin doğru olmadığı tespitine ulaştıklarını, tersine 
medya konusunda bilinçli olduklarını ancak bunun medya okuryazarlığı konusunda eğitime hiç ihtiyaçları yok anlamına da gelmeyeceğini bildirmektedir. Bu araştırma bulgularına göre de öğrencilerin puanlarına göre bağımlılık düzeylerinin düşük ve okuryazarlık düzeylerinin yüksek olması belli bir bilinç düzeyine sahip olduklarını gösterir. Nitekim pek çok akademisyen de bu eğitimin üniversite öncesinde okullarda erken dönemlerde verilmesi ve sürdürülmesi fikrinde birleşmektedirler (Akt. Algan, 2006). Öyle ki Desmond (1997, s.331), çocukların medyanın algılanmasında aile içindeki iletişimden etkilendiğinden dolayı medya okuryazarlığının evde başlaması gerektiğini düşünmektedir.

\section{Öğrencilerin Medya ve Televizyon Okuryazarlık Düzeyleri Puanlarının Bazı Değişkenlere Göre Farklılaşıp Farklılaşmamasına ilişkin Tartışma ve Yorumlar}

Bu bölümde öğrencilerin medya ve televizyon okuryazarlık düzeyleri puanlarının, cinsiyetlerine, okul türlerine, anne-baba eğitim düzeylerine, ailelerinin genel yapısına, katılmaktan hoşlandıkları etkinliklere ve bireysel özelliklerine göre anlamlı bir şekilde farklılaşıp farklılaşmamasına ilişkin tartışma ve yorumlara yer verilmiştir.

\section{Öğrencilerin medya ve televizyon okuryazarlık düzeyleri puanlarının cinsiyetlerine göre farklılaşıp farklılaşmamasına ilişkin tartışma ve yorumlar}

Öğrencilerin Medya ve TV okuryazarlık düzeyleri puanlarında cinsiyete göre anlamlı bir farklılaşma olmadığı bulgusuna ulaşılmıştır. Kartal (2007), araştırmasında 10.sınıf düzeyinde cinsiyete göre benzer bir şekilde, medya okuryazarlığı eğitimi alan öğrencilerin reklam metnini değerlendirmelerinde, görsel metni analiz etme becerilerinde, haber metnindeki mesajı algılamalarında ve dizilerdeki mesajları algılamalarında anlamlı bir farklılığa yol açmadığı bulgusuna ulaşmıştır. Dolayısı ile öğrencilerin medya ve TV okuryazarlık düzeylerinde cinsiyetin etkili olmadığı ve anlamlı bir farklılaşmaya yol açmadığı söylenilebilir.

\section{Öğrencilerin medya ve televizyon okuryazarlık düzeyleri puanlarının okul türlerine göre farklılaşıp farklılaşmamasına ilişkin tartışma ve yorumlar}

Okul türlerine göre de öğrencilerin medya ve TV okuryazarlık düzeyleri puanlarında anlamlı bir farklılaşma olmadığı bulgusuna ulaşılmıştır. Bu bulguyla ilgili, alan yazında kıyaslayacak ya da destekleyecek araştırma bulgularına rastlanılmamıştır. Ancak, bu araştırmadan çıkan bulgunun nedeni, genel olarak hangi okul türü olursa olsun medya okuryazarlığı konusuna çok fazla önem verilmemiş olmasından kaynaklanabilir. Çünkü bazı okullarda medya okuryazarlığı dersi ya da bu dersin içeriğine yakın başka isimler altında seçmeli dersler olmasına rağmen bu dersler ne öğrenciler tarafından seçilmekte ne de öğretmenler tarafından bu dersleri seçmek için öğrenciler yönlendirilmektedir. Bir başka sorun da bu dersler seçmeli olarak olmasına rağmen bu dersleri okullarda verecek uzman kişilerin olmamasıdır. Dolayısıyla, farklı okul yapılarından gelen öğrencilerin bu konuda eğitim almamış olması düzeylerinde anlamlı bir farklılaşma çıkmamasına neden olmuş olabilir. Yine, Potter (2001), medya okuryazarlığı nedir?' sorusuna; çok yönlüdür, görecelidir, kişiye göre değişir, izleyici odaklıdır. Bilince ve bilinenlere göre değişir. Herkes belli bir oranda medya okuryazarıdır, kimse tam medya okuryazarı değildir. Kısaca karmaşık bir kavramdır, yani basit değildir şeklinde cevap verir. Bu anlamda medya okuryazarlığı konusunda gurupların farklı özelliklerinden çok bireysel özelliklerin daha ağır basabileceği sonucuna ulaşılabilir.

\section{Öğrencilerin medya ve televizyon okuryazarlık düzeyleri puanlarının anne ve baba eğitim düzeylerine göre farklılaşıp farklılaşmamasına ilişkin tartışma ve yorumlar}

Araştırma bulgularına göre öğrencilerin medya ve TV okuryazarlık düzeyleri puanlarının anne baba eğitim düzeylerine göre farklılaşmadığı bulgusuna ulaşılmıştır. Aslında bu konuda ailelerin eğitim düzeyleri genel olarak yaşam biçimlerini de etkileyeceğinden öğrencilerin medya okuryazarlık düzeylerinde bir farklılaşmanın olması ve bu farklılaşmanın eğitim düzeyi yüksek ebeveynlere sahip 
öğrenciler lehine olması beklenilebilir. Ancak medya okuryazarlığı konusu oldukça karmaşık bir kavram olarak karşımıza çıkıyor. İsviçre'de 1935'te yapılan bir araştırmaya göre; 20 yaşında bir gencin zihni \%75'ini okuldan, \%25'ini aileden, kendi çevresinden, gazetelerden ve dergilerden edindiği bilgilerden oluşuyordu. 1970'te ise okul kaynaklı bilgilerin oranı \%25'e düşmüştü. Bilgilerin \%75'inin kaynağı ise çevre, radyo, TV ve gazeteler olmuştur (Topuz, 2006, s.1). Bu bilgiler öğrencilerin medya ve TV okuryazarlık düzeylerinde neden anne baba eğitim düzeyine göre anlamlı bir farklılaşma olmadığı bulgusunu da destekler niteliktedir. Dolayısı ile medya okuryazarlığı konusunda bireylerin düzeylerindeki süreklilik ve geliştirilebilirlik gibi süreçlerin yine medyanın kendinden de beslendiği ya da kaynaklandığı söylenilebilir.

\section{Öğrencilerin medya ve televizyon okuryazarlık düzeyleri puanlarının aile yapılarına göre farklılaşıp farklılaşmamasına ilişkin tartışma ve yorumlar}

Yine aynı şekilde öğrencilerin medya ve TV okuryazarlık düzeyleri puanlarında aile yapılarına göre anlamlı bir farklılaşma olmaması anne baba eğitim düzeyine göre farklılaşma olup olmaması tartışmasındaki bulgularla desteklenebilir. Öyle görünüyor ki; öğrencilerin medya ve TV okuryazarlık düzeylerini aile, okul gibi temel etmenler etkilemekle beraber bu gün çevre, radyo, TV, gazeteler, internet vb. gibi medyayı da kapsayan geniş bir ağ daha belirleyici olarak etkilemektedir. Nitekim bu araştırma bulgularına göre de öğrencilerin medya ve TV okuryazarlık düzeyi puanları üzerinde aile yapılarının belirgin ve anlamlı bir şekilde etkisi olmadığı söylenebilir.

\section{Öğrencilerin medya ve televizyon okuryazarlık düzeyleri puanlarının katılmaktan hoşlandıkları etkinliklere göre farklılaşıp farklılaşmamasına ilişkin tartışma ve yorumlar}

Araştırma bulgularına göre öğrencilerin medya ve TV okuryazarlık düzeyi puanlarının katılmaktan hoşlandıkları etkinliklere göre de farklılaşmadığı bulgusuna ulaşılmıştır. Alan yazın taramasında konuyla ilgili bir bulguya ulaşılamazken yukarıda öğrencilerin okul türlerine göre medya ve TV okuryazarlık düzeyi puanlarının farklılaşıp farklılaşmaması tartışmasında öğrencilerin okul türünden çok bireysel özelliklerinin etkili olabileceğinden söz edilmişti. Bu anlamda katılmaktan hoşlandıkları etkinlikleri de bireysel özelliklerinin bir parçası olarak kabul etmek ve bir farklılaşma beklemek makul gelebilir. Ancak bunun sadece seçim konusunda öğrencinin bireysel özelliğini yansıtabileceği, bu etkinliklerin içeriği ve ne şekilde gerçekleştirildiği konusunda bir fikir vermediği ve öğrencinin medya ve TV okuryazarlık düzeyini geliştirecek unsurları taşıyıp taşımadığını yansıtmadığı unutulmamalıdır. Yapılan araştırmalarda, bir konuda tercih yapmak yönünde değil, öğrencilerin medya konusunda eğitildikleri ya da etkinliklerin içerisine medya eğitiminin de dahil edilmesi durumunda medya okuryazarlık düzeylerinin geliştiği saptanmıştır.. Örneğin, araştırmalar okul ders programlarına medya dersleri konulduğu zaman öğrencilerin medyada gördükleri şiddeti eleştirel bir gözle yorumladıklarını, yani medya okuryazarlık düzeylerini geliştirdiklerini gösteriyor (Scharrer, 2005;Voojis ve Van Der Voort, 1993, Akt. Algan, 2006). Hobbs (1996, Akt. Kartal, 2007)' da medya okuryazarlığını dil, sanat, sosyal bilimler, sağlık ve bilim alanlarına entegre ederek alan öğrenciler, bu eğitimi almayan öğrencilere göre medyanın hedef kitlesinin ve ekonomik amaçlarının farkındalıklarının arttığını bildirmiştir.

Öğrencilerin medya ve televizyon okuryazarlık düzeyleri puanlarının bireysel özelliklerine göre farklılaşıp farklılaşmamasına ilişkin tartışma ve yorumlar

Araştırma bulguları öğrencilerin bireysel özelliklerine göre incelendiğinde ise öğrencilerin medya ve TV okuryazarlık düzeyi puanlarının bağımlılık boyutunda anlamlı bir farklılaşma olmazken ve bu puanları düşükken, okuryazarlık boyutunda puanlarının anlamlı olarak farklılaştığı ve yüksek olduğu görülmektedir. Bu bulgu; öğrencilerin medya ve TV okuryazarlık düzeylerinin okul türlerine göre farklılaşıp farklılaşmaması tartışmasında da yer verdiğimiz Potter (2001)’ın, “medya okuryazarlığı, çok 
yönlüdür, görecelidir, kişiye göre değişir, izleyici odaklıdır, bilince ve bilinenlere göre değişir" bilgisini doğrular niteliktedir. Korkmaz ve Yeşil (2011)' de bireysel özelliklere dikkat çekmiş ve ilişkiyi destekler nitelikte bilgilere yer vermiştir. Nitekim, okuryazarlık düzeyi puanlarında öğrencilerin bireysel özellikleri etkilidir ve farkılaşmaktadır. Bu farkılaşmanın kaynağı ve öğrencilerin okuryazarlık düzeyi ortalamaları incelendiğinde ise kendine güvenen öğrencilerin $(\overline{\mathrm{X}}=80.18)$ risk alabilen öğrencilerden $(\overline{\mathrm{X}}=75.97)$, düşünmeye önem veren öğrencilerin $(\overline{\mathrm{X}}=81.13)$ risk alabilen öğrencilerden $(\overline{\mathrm{X}}=75.97)$ ve kendine güvenen öğrencilerden ( $\overline{\mathrm{X}}=80.18)$, yaratıcı öğrencilerin $(\overline{\mathrm{X}}=82.95)$ girişken $(\overline{\mathrm{X}}=76.70)$, risk alabilen $(\overline{\mathrm{X}}=$ 75.97) ve kendine güvenen öğrencilerden ( $\bar{X}=80.18)$, sorgulayıcı öğrencilerin $(\bar{X}=85.92)$, girişken $(\bar{X}=$ 76.70), risk alabilen $(\bar{X}=75.97)$, sorumluluk üstlenebilen $(\bar{X}=79.44)$, kendine güvenen $(\bar{X}=80.18)$, yeni fikirlere açık ( $\bar{X}=79.19)$ ve insancıl ( $\bar{X}=78.65)$ öğrencilerden farklılaştıkları ve medya ve TV okuryazarlık düzeylerinin daha gelişmiş olduğu bulgularına ulaşılmıştır. Bu bulgulara göre en fazla farklılaşmanın yaratıcı ve sorgulayıcı özelliğe sahip öğrencilerin okuryazarlık düzeyi puanlarında olduğu; yani bu özelliklere sahip öğrencilerin okuryazarlık puanlarının daha yüksek ve gelişmiş olduğu görülmüştür. Medya okuryazarlığı, yazılı ve yazılı olmayan farklı formatlardaki (televizyon, video, sinema, reklamlar, internet vs.) iletilere erişim, onları çözümleme, değerlendirme ve iletme yeteneği olarak tanımlanmaktadır. Center for Media Literacy'nin (Medya Okuryazarlığı Merkezi) kurucusu ve Başkanı Elizabeth Thoman; medya okuryazarlığının, öğrencilerin yalnızca gördükleri medya ürününü okumalarını değil, aynı zamanda onu yaratma sürecinde de etkin rol almalarını gerektiren bir hareket olduğunu vurgular (İnceoğlu, 2006, s4). Aufderheide (1993) yaratıcılık boyutuna dikkat çekerek, medya okuryazarlık becerisine sahip bireyleri "tüm medyalarla ilişkisinde eleştirel bir özerkliğe sahip tüm basılı ve elektronik medyaları analiz eden, değerlendiren ve yeniden şekillendirerek iletebilen bireyler olarak tanımlamaktadır. Yine Livingstone (2004, s. 4-8)'de mesaj üretme deneyimi olan çocukların, medya mesajlarına karşı daha bilinçli olacaklarını savunmaktadır. Medya okuryazarlığının özünde sorgulama vardır. Thoman (2003)' a göre de farklı medya formları arasındaki farkı ayırt etmeye ve izlediğimiz, duyduğumuz ve okuduğumuz her şey hakkında temel soruları nasıl soracağımızı bilmeye ihtiyacımız vardır (Kartal, 2007, s.19). Medya okuryazarlığı eğitiminin önemi konusunda RTÜK (2008), illköğretim Medya Okuryazarlığı Dersi Öğretmen El Kitabında sorgulama boyutu üzerinde durarak bireylerin neyin iyi neyin kötü, neyin yararlı neyin zararlı olduğunu ayırt etmeleri gerektiğini açıklayarak eleştirel bir bakış açısıyla pasif alıcılar yerine aktif bir pozisyonda yer almaları gerektiğini vurgulamaktadır. Nitekim araştırmadan elde edilen bulgularda da yaratıcı ve özellikle sorgulayıcı özelliğe sahip öğrencilerin medya ve TV okuryazarlık düzeyi puanları daha yüksek çıkarak diğer özelliklere sahip olan öğrencilerden farklılaşmış ve daha gelişmiştir. Sonuç olarak yaratıcı ve özellikle sorgulayıcı özelliğe sahip öğrencilerin medya ve TV okuryazarlık düzeylerinin daha gelişmiş olduğu söylenebilir.

\section{Öğrencilerin Medya ve Televizyon Okuryazarlık Düzeyleri Puanları ve Akademik Başarı Puanları Arasındaki İlişkiye Yönelik Tartışma ve Yorumlar}

Öğrencilerin medya ve TV okuryazarlık düzeyleri puanları ile akademik başarı puanları arasındaki korelasyon değerleri incelendiğinde p>0.05 olduğu yani anlamlı bir ilişki olmadığı sonucuna ulaşılmıştır. Konuyla ilgili alan yazında böyle bir bulguya rastlanmamıştır. Bu gün bilgi toplumunun insanlarının medya ve televizyon aracılığıyla bilgiye ulaşmasını, ulaştığı bilgilere eleştirel yaklaşmasını ve sorgulayıcı olmasını; bir başka ifade ile medya ve televizyon okuryazarı olmasını gerektirmektedir. Bununla birlikte medya ve televizyon aracılığıyla insanların bilinçsiz olarak ve önemli düzeyde yönlendirilmeye açık oldukları; insanların çoğu kez okudukları ya da izledikleri haberleri irdelemeksizin kabul ederek tepkiler geliştirdikleri, alan yazında sıklıkla dile getirilen konulardan biri olmaya devam etmektedir (Korkmaz ve Yeşil, 2011, s. 113). Hayata ve gündeme dönük pek çok bilgi ve okul ders programlarımızın ilişkisi düşünüldüğünde medya ve TV okuryazarlık düzeyi ile akademik başarı arasında bir bağ kurmak olasıdır. Bu durum okul ders programlarımızın hayatla ne kadar ilişkisi var sorusunu da düşündürmektedir. Bu anlamda öğrencilerin medya ve TV okuryazarlık düzeyleri ile akademik başarıları arasında anlamlı bir ilişki olmaması bulgusu, okul programlarının hayat ve gündemle olan ilişkisinin de sorgulanmasını gerekliliğini ortaya koyabilir. Nitekim Hobbs'a (1998) göre medya okuryazarlığı eğitiminde popüler kültür metinlerinin çözümlenmesi özellikle lise ve üniversite öğretim elemanları için olmazsa olmaz bir nitelik 
taşımaktadır. Korkmaz ve Yeşil (2011), Türkiye'de öğretmenlerin merkezci bir müfredatı takip ettiklerinden, kitaba bağlı ezberci bir sistem uyguladıklarından ve okullarda medya donanımlarının eksikliğinden ötürü Hobbs'un bu sorusunu bizim tartışmamıza pek gerek olmadığını bildirmektedir. Dolayısıyla bu araştırmada da medya okuryazarlığı ile akademik başarı arasında bir ilişki çıkmaması, eğitim sistemimizin her ne kadar ders programları değişmiş olsa da uygulamada daha çok geleneksel bir öğretim sürecinin izlenmesinden kaynaklanabilir.

\section{Öneriler}

Medya Okuryazarlığı dersi 2007-2008 öğretim yılında ilköğretim II. kademede seçmeli ders olarak okutulmaya başlanmıştır. (RTÜK, 2008). Ancak pek çok akademisyen bu eğitimin daha erken yaşlarda verilmesi gerektiği konusunda hemfikirdir (Algan, 2006). Öyle ki Desmond (1997) bu eğitimin evde başlaması gerektiğini vurgulamaktadır. Dünyada gelişmiş ülkelerde Medya Okuryazarlığı eğitimi değişik seviyelerde direk ders olarak ya da farklı ders müfredatlarının içerisinde verilmektedir (RTÜK, 2008). Bu bilgiler doğrultusunda Medya Okuryazarlığına ilişkin ders ya da çalışmalara ilkokul programlarına da yansıyacak ve disiplinler arası verilecek şekilde daha erken yaşlarda başlanılmalıdır.

Okullarda Medya okuryazarlığı dersi bu alanda uzman olan kişiler tarafından verilmeli ya da bu dersi verecek öğretmenler bu alana yönelik kuramsal ve uygulamalı hizmetiçi eğitim programları aracılığıyla yetiştirilmelidir.

Ailelerin de daha bilinçli medya okuryazar olan çocuklar yetiştirebilmeleri için öncelikle onların medya okuryazarlığı konusunda eğitilmiş olmaları gerekmektedir. Bu nedenle öncelikle ailelere yaygın eğitim yoluyla medya okuryazarlığı eğitimi, uzman kişiler tarafından verilmelidir.

İlköğretim Medya Okuryazarlığı Dersi Programı incelendiğinde; iletişim, medya, toplum, kültür, ekonomi ve kitle iletişim araçları gibi pek çok konu başlığına yer verildiği görülmektedir (MEB ve RTÜK, 2006). Ancak medyanın gücü ve zararlı etkileri konusunda açık bir bölüm bulunmamaktadır. Bu programa, öğrencilerin günlük yaşamda karşılaşabilecekleri, açık olarak algılayabilecekleri dünyada ve ülkemizdeki olgulara yönelik konu başlıkları ilave edilmeli ve detaylandırılmalıdır.

\section{Kaynaklar}

Algan, E. (2006). Medya okuryazarlığı alanında teorik ve pratik yaklaşımlar, medya okuryazarlığı, (Ed. N. Türkoğlu). 23-25 Mayıs 2005, I. Uluslararası Medya Okuryazarlığı Konferansı, Marmara Üniversitesi Iletişim Fakültesi Yayınları, İstanbul.

Aufderheide, P. (1993). Media literacy: A report of the national leadership conference on media literacy. Washington: DC, Aspen Institute.

Çelik, M. (2008). Egemen ideolojinin bir aracı olarak medya ve eleştirel farkındalığın gerekliliği: Medya okuryazarlığı. Unpublished doctoral dissertation, Marmara Üniversitesi, İstanbul.

Desmond, R. (1997). Media literacy in the home: Acquisition versus deficit models. In Kubey, R (Ed.), Media literacy in the information age: Current perspectives (pp. 323-344). New Brunswick, NJ: Transaction Publishers.

Hobbs, R. (1998). The seven great debates in the media literacy movement. Journal of Communication, 48(1),16-32.

Hobbs, R. (2004). Medya okuryazarlığı hareketinde yedi büyük tartışma (Trans. M. T. Bağlı). Ankara Üniversitesi Eğitim Bilimleri Fakültesi Dergisi, 37(1), 122-140.

İnceoğlu, Y. (2006). Medyayı doğru okumak (Ed. N. Türkoğlu). 23-25 Mayıs 2005, I. Uluslararası Medya Okuryazarlığı Konferansı, Marmara Üniversitesi İletişim Fakültesi Yayınları, İstanbul. 
Birsel AYBEK ve Remzi DEMIR - Çukurova Üniversitesi Eğitim Fakültesi Dergisi, 43(1), 2014, 46-62

Jolls, E. \& Thoman, T. (2008). 21. yüzyıl okuryazarlığı (Trans. C. Elma ve A. Kesten). Ankara: Ekinoks Yayıncılık.

Karaman, K. \& Karataş, A. (2009). Öğretmen adaylarının medya okuryazarlık düzeyleri. Ilköğretim Online, $8(3), 798-808$.

Karasar, N. (1998). Bilimsel araştırma yöntemi (9. Ed.). Ankara: Nobel Yayın Dağıtım.

Kartal, O. Y. (2007). Ortaöğretim 10. sını öğrencilerinin televizyon dizilerindeki mesajları algılamalarında medya okuryazarlığının etkisi. Unpublished Master's Thesis, Çanakkale Onsekiz Mart Üniversitesi, Çanakkale.

Korkmaz, Ö. \& Yeşil, R. (2009). Öğretim kademelerine göre öğrencilerin eleştirel düşünme düzeyleri. Ahi Evran Üniversitesi Eğitim Fakültesi Dergisi, 10(2), 19-28.

Korkmaz, Ö. \& Yeşil,R. (2011). Medya ve televizyon okuryazarlık düzeyleri ölçeği geçerlilik ve güvenirlik çalışması. Uluslararası Insan Bilimleri Dergisi, 8(2), 110-126.

Kökdemir, D. (2003). Belirsizlik durumlarında karar verme ve problem çözme. Unpublished doctoral dissertation, Ankara Üniversitesi, Ankara.

Kurt, A. A. \& Kürüm, D. (2010). Medya okuryazarlığı ve eleştirel düşünme arasındaki ilişki: Kavramsal bir bakış. Mehmet Akif Ersoy Üniversitesi Sosyal Bilimler Enstitüsü Dergisi, 2, 20-34.

Livingstone, S. (2004). Media literacy and the challenge of new information and communication Technologies. The Communication Review, 7, 3-14.

MEB \& RTÜK. (2006). Ilköğretim Medya Okuryazarlığı Dersi Öğretim Programı ve Kılavuzu, Ankara: MEB Yayınları.

MEB. (2009). Medya okuryazarlığı dersi öğretmen kılavuz kitabı (2. Ed). İstanbul: Devlet Kitapları.

Merter, F. (2009). Cumhuriyet-Dicle-İnönü Üniversitesi Eğitim Fakültesi İlköğretim Bölümü öğrencilerinin öğrenme stilleri ve öğrenme stillerini farklılaştıran sosyo-ekonomik faktörler. Dicle Üniversitesi Ziya Gökalp Eğitim Fakültesi Dergisi, 13, 78-96.

RTÜK, (2008). ilköğretim medya okuryazarlığı dersi öğretmen el kitabı. Retrieved August 09, 2011, from http://www.medyaokuryazarligi.org.tr/kaynaklar/MEDYAlkitabK.doc.

Topuz, H.(2006). Medya Eğitimi: Medya Çözümlemesi, (Ed. N. Türkoğlu). 23-25 Mayıs 2005, I. Uluslararası Medya Okuryazarlığı Konferansı, Marmara Üniversitesi İletişim Fakültesi Yayınları, İstanbul. 